\title{
SOME ASPECTS OF BONE MARROW METABOLISM
}

\author{
By Dr. C. LUTWAK-MANN \\ Biochemical Laboratory, University of Cambridge
}

$\mathrm{O}$ WING to its inaccessibility and the relatively small amount present in the body, bone marrow until recently has received less attention from the biochemist than is warranted by its great biological significance, which has been established on the basis of brematological studies. The object of this investigation was to accumulate facts concerning certain important cell constituents of bone marrow in the hope that this would contribute towards a better understanding of bone marrow metabolism, and that the information gained would open up a possibility of a quantitative assessment of bone marrow activity under normal and pathological conditions.

Young adult rats and rabbits served as experimental animals ; the bone marrow was obtained from the long bones (femur, tibia, humerus). The analytical results below are given in $\mathrm{mgm}$. per $100 \mathrm{gm}$. fresh weight.

Distribution and breakdown of phosphorus compounds in bone marrow. Results obtained with four sets of litter-mate rabbits belonging to different breeds are given in Table 1, from which it can be seen that whereas there are considerable variations in the concentration of the phosphorus compounds between the litters, there is fairly good agreement between litter-mates. As regards acid-soluble phosphate, the fluctuations in the level of inorganic phosphate may be partly due to phosphatase activity of bone marrow referred to later. There is more readily-hydrolysable phosphate than corresponds to adenylpyrophosphate, suggesting the presence of yet another acid-labile phosphate ester'. 'The variations in the actual level of adenylpyrophosphate in fresh bone marrow may be partly, but not entirely, due to enzymic breakdown, because although rabbit bone marrow is capable of decomposing it by dephosphorylation and deamination, these enzymes are not very strong, and the presence of preformed adenylpyrophosphate could be demonstrated in bone marrow suspensions after several hours incubation, especially under aerobic conditions.

Lipid phosphorus varied little from one set of liftermates to another, but the differences in nucleic acid phosphorus were considerable. As the content of nucleic acid presumably depends upon the cellularity of the bone marrow, these values are a good indicator of the metabolic potential of the tissue. Corroboration

Table 1. Phosphate distribution in rabbit bone marrow

\begin{tabular}{|c|c|c|c|c|c|c|c|}
\hline \multirow{3}{*}{$\begin{array}{c}\text { Rabbit } \\
\text { litter }\end{array}$} & \multicolumn{7}{|c|}{$P$ in mgm. per $100 \mathrm{gm}$. fresh weight bone marrow } \\
\hline & \multirow{2}{*}{$\begin{array}{l}\text { Inorg- } \\
\text { anic }\end{array}$} & \multirow{2}{*}{$\begin{array}{l}\text { Readily } \\
\text { hydro- } \\
\text { lysable }\end{array}$} & \multicolumn{2}{|c|}{$\begin{array}{l}\text { Adenylpyro- } \\
\text { phosphate }\end{array}$} & \multirow{2}{*}{$\begin{array}{c}\text { Total } \\
\text { acid- } \\
\text { soluble }\end{array}$} & \multirow{2}{*}{ Lipid } & \multirow{2}{*}{$\begin{array}{c}\text { Nucleic } \\
\text { acid }\end{array}$} \\
\hline & & & pyro-P & $\mathrm{NH}_{\mathbf{3}}-\mathrm{N}$ & & & \\
\hline $\begin{aligned} & 1 \\
& 2 \\
& 3 \\
& 4\end{aligned}$ & $\begin{array}{l}7 \cdot 80 \\
4 \cdot 60 \\
5 \cdot 90 \\
6 \cdot 00\end{array}$ & $\begin{array}{l}4 \cdot 90 \\
9 \cdot 00 \\
7 \cdot 80 \\
8 \cdot 20\end{array}$ & $\begin{array}{l}2 \cdot 48 \\
3 \cdot 01 \\
4 \cdot 87 \\
4 \cdot 34\end{array}$ & $\begin{array}{l}0.56 \\
0.68 \\
1.10 \\
0.98\end{array}$ & $\begin{array}{l}43 \cdot 00 \\
48 \cdot 00 \\
40 \cdot 00 \\
41 \cdot 00\end{array}$ & E & $\begin{array}{r}113.00 \\
123.00 \\
98.00 \\
120.00\end{array}$ \\
\hline II $\begin{array}{l}1 \\
2 \\
3\end{array}$ & $\begin{array}{l}4 \cdot 50 \\
4 \cdot 00 \\
3 \cdot 80\end{array}$ & $\begin{array}{r}11 \cdot 00 \\
7 \cdot 50 \\
10 \cdot 00\end{array}$ & $\begin{array}{l}6 \cdot 64 \\
5 \cdot 23 \\
4 \cdot 34\end{array}$ & $\begin{array}{l}1 \cdot 50 \\
1 \cdot 18 \\
0 \cdot 98\end{array}$ & $\begin{array}{l}32 \cdot 00 \\
33 \cdot 00 \\
35 \cdot 00\end{array}$ & $\begin{array}{l}27 \cdot 00 \\
32 \cdot 00 \\
30 \cdot 00\end{array}$ & $\begin{array}{l}57 \cdot 00 \\
62 \cdot 00 \\
60 \cdot 00\end{array}$ \\
\hline III $\begin{array}{l}1 \\
2\end{array}$ & $\begin{array}{l}5 \cdot 20 \\
8 \cdot 30\end{array}$ & $\begin{array}{r}7 \cdot 60 \\
11 \cdot 00\end{array}$ & $\begin{array}{l}3 \cdot 18 \\
3 \cdot 99\end{array}$ & $\begin{array}{l}0.72 \\
0.90\end{array}$ & $\begin{array}{l}37 \cdot 00 \\
36 \cdot 00\end{array}$ & $\begin{array}{l}30 \cdot 00 \\
36 \cdot 00\end{array}$ & $\begin{array}{l}72 \cdot 00 \\
79 \cdot 00\end{array}$ \\
\hline IV $\begin{array}{l}1 \\
\\
\end{array}$ & $\begin{array}{l}6 \cdot 20 \\
7 \cdot 30\end{array}$ & $\begin{array}{l}3 \cdot 60 \\
5 \cdot 00\end{array}$ & $\begin{array}{l}1 \cdot 68 \\
1 \cdot 99\end{array}$ & $\begin{array}{l}0.38 \\
0.45\end{array}$ & $\begin{array}{l}38 \cdot 00 \\
40 \cdot 00\end{array}$ & $\begin{array}{l}37 \cdot 00 \\
34 \cdot 00\end{array}$ & $\begin{array}{l}88 \cdot 00 \\
91 \cdot 00\end{array}$ \\
\hline
\end{tabular}

of this assumption was derived from experiments in which glycolysis and respiration were determined parallel with nucleic acid phosphorus; bone marrow, where the level of nucleic acid phosphorus was high, showed invariably much more vigorous metabolic activity than samples where its content was low.

In rat bone marrow total acid-soluble phosphate was 80-90 mgm. per cent, compared with 30-48 mgm. per cent in rabbit. Nucleic acid phosphorus was also much higher than in rabbit bone marrow. A distinct sex difference was established in the content of nucleic acid phosphorus in rat bone marrow, as seen in Table 2 ; vitamin B deficiency considerably lowered the level of this phosphorus fraction, but castration, either itself or followed by prolonged treatment with testosterone propionate, or progesterone, affected these values to a small extent.

Table 2. Nucleic acid phosphorus in rat bone marrow

\begin{tabular}{|c|c|c|c|c|c|c|}
\hline \multirow[b]{2}{*}{ Rats } & \multicolumn{6}{|c|}{$\mathrm{P}$ in mgm. per $100 \mathrm{gm}$. fresh weight bone marrow } \\
\hline & đa & 우 & $\begin{array}{c}0 \text { cast- } \\
\text { rates }\end{array}$ & $\begin{array}{l}\text { o cast- } \\
\text { rates + } \\
\text { testos- } \\
\text { terone }\end{array}$ & $\begin{array}{c}\text { o cast- } \\
\text { rates + } \\
\text { proges- } \\
\text { terone }\end{array}$ & $\begin{array}{l}\text { o, B-de- } \\
\text { flcient }\end{array}$ \\
\hline Hooded & $260-300$ & $220-260$ & $250-270$ & $260-280$ & & $140-190$ \\
\hline Albino & 240,260 & & 218,220 & & 230,240 & \\
\hline
\end{tabular}

With hooded rats, highest and lowest values were based on groups of 10-20 animals; with albino rats two animals were used for each experiment.

When suspensions of rabbit bone marrow were incubated at $24^{\circ}$ for four hours, the inorganic phosphate rose considerably, particularly under anaerobic conditions, at the expense of difficultly hydrolysable phosphate esters; under such experimental conditions total acid-soluble phosphate remained unchanged, and there was no breakdown of nucleic acid phosphorus. On the other hand, incubation of rat bone marrow for one hour at $38^{\circ}$ produced a significant fall in nucleic acid phosphorus, which was not affected by $M / 50$ fluoride. Both rabbit and rat bone marrow dephosphorylated readily various added phosphate esters concerned with glycolysis.

Ammonia formation. Incubation of bone marrow in saline, water or phosphate caused the accumulation of considerable amounts of ammonia. After 2-4 hours at room temperature, 3-5 mgm. per cent ammonia was found in rabbit bone marrow; aliquot samples examined simultaneously for their content of adenylpyrophosphate showed sometimes as much as a half to a third of it still present. In any event, the quantities of ammonia produced far exceeded those which could have been derived from total deamination of adenylpyrophosphate in rabbit bone marrow (Table 1).

In rat bone marrow incubated for 1-2 hours at $38^{\circ}, 30-40 \mathrm{mgm}$, per cent ammonia was found. Parallel with bone marrow, samples of whole blood of rats and rabbits were incubated, but the amounts in bone marrow considerably exceeded ammonia produced in blood. Ammonia formation in bone marrow was not dependent upon oxygen, and it was not inhibited by fluoride, iodoacetate or toluene.

Other enzymes. In addition to enzymes capable of readily converting glucose, fructose and mannose, 
but not glycogen or galactose, to lactic acid, bone marrow showed carbonic anhydrase, choline esterase and methylglyoxylase activity. The presence of deaminases in bone marrow was reported earlier ${ }^{1}$.

Various metabolites in bone marrow. Rabbit bone marrow contained 50-100 mgm. per cent glycogen; total reducing sugar was 25-33 $\mathrm{mgm}$. per cent, of which 2-4 mgm. per cent was true glucose as determined by means of glucose oxidase (notatin). Fructose was absent. Rabbit bone marrow contained $0.5 \mathrm{mgm}$. per gm. glutathione and $0.08 \mathrm{mgm}$. per gm. ascorbic acid. Citric acid was $3.5 \mathrm{mgm}$. per cent in rabbit, and $5 \mathrm{mgm}$. per cent in rat bone marrow (rat long bones contained $320 \mathrm{mgm}$. per cent citric acid). Nonprotein nitrogen in rabbit bone marrow was $75-$ $100 \mathrm{mgm}$. per cent, polypeptide nitrogen $8.5 \mathrm{mgm}$. per cent, amide nitrogen $75-100 \mathrm{mgm}$. per cent; $2 \cdot 7-3 \cdot 0 \mathrm{mgm}$. per cent amide nitrogen was in the protein-free filtrate.

Metals. Copper, zinc and iron were estimated in rabbit bone marrow. The copper content varied from 0.126 to $0.3 \mathrm{mgm}$. per cent, and exceeded amounts in rabbit blood. Zine was $1 \cdot 37 \mathrm{mgm}$. per cent. Iron in bone marrow was estimated simultaneously with the hæmatin content; it was found that a considerable proportion of rabbit bone marrow iron, sometimes as much as two-thirds, was non-hæmatin iron.

Effect of various agents upon bone marrow metabolism. (a) In vitro. The effect of the following substances in $M / 200$ to $M / 400$ concentration upon the anaerobic glycolysis of rat and rabbit bone marrow was investigated: fluoride, iodoacetate, mustard gas, mustard sulphoxide and sulphone, urethane, dimethyldithiocarbamate, amidopyrine, nitrobenzene, sulphanilamide, hydroquinone. Fluoride and iodoacetate, also mustard gas (confirming earlier work by Needham, Cohen and Barrett ${ }^{2}$ ) and mustard sulphone, but not mustard sulphoxide, all inhibited bone marrow glycolysis. Of the other substances, only amidopyrine had an inhibitory eftect, especially in rat bone marrow.

(b) In vivo. The mode of application, dose and systemic effects of mustard gas, sulphoxide and sulphone in rats and rabbits and their action upon bone marrow glycolysis were reported earlier ${ }^{3}$. Table 3 shows the characteristic changes in acidsoluble and nucleic acid phosphorus in rat bone marrow following treatment with mustard gas and mustard sulphoxide, the latter alone and together with dimethyldithiocarbamate (dimethyldithiocarbamate was introduced into mustard gas studies by G. R. Cameron and H. N. Rydon; Porton Report, 1944). The remarkable 'mustard gas-like' 'action of very small amounts of sulphoxide in combination with dimethyldithiocarbamate, in contrast to the relative inactivity of either of these substances alone, was demonstrated befor $\theta^{3}$, but no study of phosphate distribution was made at that time. Dimethyldithiocarbamate could be replaced in such experiments by diethyldithiocarbamate, but not by ethylcarbamate (urethane).

No striking efrects upon bone marrow glycolysis or nucleic acid phosphorus were observed following prolonged administration to rats of lead salts, sulphasuxidine, urethane or amidopyrine.

The adverse effect of total body exposure to X-rays upon bone marrow metabolism was described recently ${ }^{4}$. On the other hand, direct in vitro irradiation of bone marrow with $20,000 \mathrm{r}$. had no efiect upon glycolysis or nucleic acid phosphorus.
Table 3. Effect of mustard gas and mustard sulphoxide upon acidsoluble and nucleic acid phosphorus in rat bone marrow

\begin{tabular}{|c|c|c|c|}
\hline \multirow{2}{*}{ Treatment } & \multirow{2}{*}{$\begin{array}{c}\text { Days } \\
\text { after } \\
\text { treatment }\end{array}$} & \multicolumn{2}{|c|}{$\begin{array}{l}P \text { in mgm. per } 100 \mathrm{gm} \text {. fresh } \\
\text { weight bone marrow }\end{array}$} \\
\hline & & $\begin{array}{l}\text { Total acid- } \\
\text { soluble P }\end{array}$ & Nucleic acid $P$ \\
\hline Untreated control & 0 & 88 & 287 \\
\hline $\begin{array}{l}\text { Mustard gas, } 0 \cdot 1 \text { ml. } \\
4 \% \text { solution in ethyl- } \\
\text { ene glycol ether, cut- } \\
\text { aneous application }\end{array}$ & $\begin{array}{l}2 \\
4 \\
6 \\
8 \\
8\end{array}$ & $\begin{array}{r}55^{*} \\
111 \\
94 \\
78 \\
\end{array}$ & $\begin{array}{l}58^{*} \\
200 \\
240 \\
235 \\
\end{array}$ \\
\hline $\begin{array}{l}\text { Mustard sulphoxide, } \\
0.01 \mathrm{mgm} \text {./gm., subcut- } \\
\text { aneous injection }\end{array}$ & $\begin{array}{l}2 \\
4 \\
6\end{array}$ & $\begin{array}{l}79 \\
80 \\
90\end{array}$ & $\begin{array}{l}247 \\
240 \\
260\end{array}$ \\
\hline $\begin{array}{l}\text { Mustard sulphoxide, } \\
0.01 \text { mgm./gm., plus } \\
\text { dimethyldithiocarba- } \\
\text { mate, } 0 \cdot 1 \text { mgm./gm., } \\
\text { subcutaneous injection }\end{array}$ & $\begin{array}{l}2 \\
4 \\
6 \\
8 \\
\end{array}$ & $\begin{array}{r}58^{*} \\
113 \\
120 \\
98\end{array}$ & $\begin{array}{l}88^{*} \\
240 \\
224 \\
247\end{array}$ \\
\hline $\begin{array}{l}\text { Dimethyldithiocarba- } \\
\text { mate, } 0 \cdot 1 \text { mgm./gm., } \\
\text { subcutaneous in- } \\
\text { jection }\end{array}$ & $\begin{array}{l}2 \\
4 \\
6\end{array}$ & $\begin{array}{l}68 \\
72 \\
78\end{array}$ & $\begin{array}{l}265 \\
250 \\
260\end{array}$ \\
\hline
\end{tabular}

* Bone marrow of grossly altered, fluid consistency, with consider able admixture of blood.

Some of the experiments with mustard gas and its derivatives were carried out as part of extra-mural studies on behalf of the Ministry of Supply; thanks are due to the Chief Scientist, Ministry of Supply, for permission to publish the results. The study of bone marrow metabolism is supported by a personal grant to the author from the Medical Research Council.

${ }^{1}$ Lutwak-Mann, C., Biochem. J., 41, Proc. $\mathrm{xxx}$ (1947).

${ }^{2}$ Needham, D. M., Cohen, J. A., and Barrett, A. M., Biochem. J., 41, 631 (1947).

${ }^{3}$ Lutwak-Mann, C., Report to Ministry of Supply by Dr. Malcolm Dixon, No. 32 (1947).

' Lutwak-Mann, C., and Gunz, F. W., Biochem. J., 44, Proc. iii (1949).

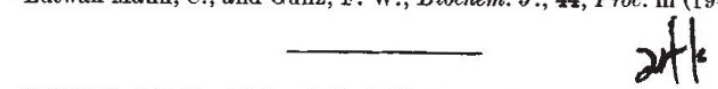

\section{SCIENCE IN ADLYLT EDUCATION}

TWO years ago, at Iftindee the Council of the British Associatigrasked the Education Section to consider frhof pould be done to stimulate more interest in scobe in the sphere of adult education. As a yesut acommittpento explore this question was esthe fished joint 1 y the National Foundation for Adul Educatio find the British Association; and it has recently issued an interim report. One of the sessions of the Education Section of the British Association at the Newcastle meeting was devoted to a discussion of this report.

The discussion was opened by Mr. W. O. Lester Smith, who had been chairman of the joint committee. Emphasizing the interim character of the report, he said that the aim of the committee has been to produce some practical suggestions which might bring early results; they are well aware, however, that there are fundamental issues which require consideration and that there is room for a report of a long-term character. He paid a tribute to the services rendered by Mr. E. M. Hutchinson as secretary of the joint committee, and commented upon the help given by directors of extra-mural departments and secretaries of Workers' Educational Association districts, and also by many tutors, especially those who are actively engaged in promoting courses in scientific studies.

The president of the Education Section, Sir Fred Clarke, was in the chair, and he rightly described the discussion as valuable and helpful. Among the many 